\title{
The trace fossil Arachnostega in the Ordovician of Estonia (Baltica)
}

\author{
Olev Vinn, Mark A. Wilson, Michał Zatoń, and Ursula Toom
}

\begin{abstract}
In the Ordovician of Baltica, burrows assigned to the ichnogenus Arachnostega Bertling, 1992 occur in steinkerns of bivalves, cephalopods, gastropods and hyolithids. Arachnostega abundance decreased significantly during the Ordovician in Baltica. It was most abundant in the Darriwilian (17\% of gastropod steinkerns), slightly less abundant in the Sandbian (11\% of gastropod steinkerns) and least abundant in the Katian (3\% of gastropod steinkerns). This change in Arachnostega abundance correlates well with the regional climatic change (from temperate to tropics) during this interval, along with resulting changes in sedimentary environment, geochemistry and biota. Arachnostega was substrate selective and preferred bivalves over gastropods. Arachnostega occurs only in the Middle and Upper Ordovician of Estonia and is absent in the Lower Ordovician.
\end{abstract}

Olev Vinn. Department of Geology, University of Tartu, Ravila 14A, 50411 Tartu, Estonia; olev.vinn@ut.ee Mark A. Wilson. Department of Geology, The College of Wooster, Ohio, 44691 USA;

mwilson@wooster.edu

Michał Zatoń. Department of Palaeontology \& Stratigraphy, University of Silesia, Będzińska 60, 41-200

Sosnowiec, Poland; mzaton@wnoz.us.edu.pl

Ursula Toom. Institute of Geology, Tallinn University of Technology, Ehitajate tee 5, Tallinn;

ursula.toom@ttu.ee

Keywords: Trace fossils; burrows; worms; steinkern; carbonate rocks

\section{INTRODUCTION}

The ichnogenus Arachnostega was originally described from the Upper Jurassic of Germany (Bertling, 1992). The earliest Arachnostega traces are known from the Cambrian (Gil Cid and Lebrón Moreno, 2010; Fatka et al., 2011; Fatka and Kozák, 2014). They became common in the Ordovician, achieving a global distribution (e.g., Aceñolaza et al., 2013). Arachnostega traces constitute irregular, branching burrows in the sediment fill of shells; it is visible on the surface of steinkerns. Previously, Arachnostega has been reported from Ordovician of African and South American Gondwana, but it is especially widespread in European peri-Gondwana. It has only rarely been recognized in Ordovician sediments of Baltica and Kazakhstania (Fatka 
et al., 2011). There is only a single record of Arachnostega from the Ordovician of Baltica (Mikulás and Dronov, 2005). Mikuláš and Dronov (2005) briefly described the ichnogenus from the Middle Ordovician of the St. Petersburg region, Russia. Most post-Ordovician Arachnostega traces appear to occur in clastic sediments (Fatka et al., 2011). After the Ordovician there are probable peaks of Arachnostega abundance in the Devonian, Jurassic, Neogene and Quaternary (Fatka et al., 2011). However, we must consider that, once exploited, the sheltered niche produced when nutrient-bearing sediment fills a shell would likely have remained exploited. Thus, these abundance "peaks" may be due to collection or preservation bias.

Arachnostega was probably a feeding trace (fodichnion), but the possibility that Arachnostega represents a dwelling burrow (domichnion) cannot be excluded with certainty (Fatka et al., 2011). The exact paleoecology of Arachnostega is not well understood.

During the Ordovician, Baltica migrated from a temperate climate to the tropics (Torsvik et al., 1992; Cocks and Torsvik, 2005). This climatic and corresponding sedimentological change is well recorded in the Middle to Late Ordovician carbonate rocks of northern Estonia (Nestor and Einasto, 1997). The relatively complete Ordovician (all stages are represented) section of north Estonia is rich in potential substrates (i.e., shells filled with sediment) for Arachnostega.

This paper addresses the following questions: 1) Is Arachnostega common in the Ordovician of Baltica? 2) Does the abundance of Arachnostega change during the Ordovician in Baltica? If it does, do such changes correlate with climatic change (temperate versus tropical climate)? 3) Was the Arachnostega trace-maker substrate and shell selective? 4) Are the dimensions of Arachnostega burrows different in different shells? 5) Do the dimensions of Arachnostega change through the Ordovician?

\section{GEOLOGICAL BACKGROUND AND SETTING}

The Ordovician limestones of Estonia are exposed as a wide belt from the Narva River in the northeast to Hiiumaa Island in the west (Mõtus and Hints, 2007). The total thickness of the Ordovician system in Estonia varies from 70 to $180 \mathrm{~m}$ (Mõtus and Hints, 2007). In the Middle Ordovician and early Late Ordovician, the western part of the EastEuropean Platform was covered by a shallow, epicontinental sea with little bathymetric differentia- tion. This basin was characterized by an extremely low sedimentation rate (Mõtus and Hints, 2007). Along the entire extent of the ramp a series of grey calcareous - argillaceous sediments accumulated, represented now by argillaceous limestones and marls. There was a trend in sedimentation of increasing clay and decreasing bioclasts in the offshore direction (Nestor and Einasto, 1997). During the Ordovician the Baltica paleocontinent moved from the temperate climatic zone to the subtropical realm (Torsvik et al., 1992; Nestor and Einasto, 1997). In the Middle and Late Ordovician the climatic change resulted in an increase in carbonate production and sedimentation rate on the carbonate shelf. During the Late Ordovician the first carbonate buildups appeared, emphasizing a striking change in the overall character of the paleobasin (Mõtus and Hints, 2007).

\section{MATERIAL AND METHODS}

A large collection of Ordovician (Darriwilian to Hirnantian) gastropods ( $N=771)$ from northern Estonia (Figure 1) was systematically searched for the Arachnostega traces. In addition, a collection of gastropods $(\mathrm{N}=506)$, bivalves $(\mathrm{N}=106)$, cephalopods $(\mathrm{N}=70)$ and hyolithids $(\mathrm{N}=16)$ from the Aluvere Quarry (Sandbian) was systematically searched for these traces as well. Other faunal groups, such as trilobites and echinoderms, were also examined for Arachnostega traces. All the studied samples derive from limestone with various amounts of clay and bioclastic material. Echinoderm and trilobite fossils did not possess Arachnostega traces for unknown reasons.

Kunda Regional Stage (lower Darriwilian) (Mäeküla locality, Nõmmeveski locality, Tsitre locality, Kunda-Ojaküla locality, Aseri cliff, Aseri quarry): limestones and sandy limestones with iron ooids and layers of marly limestones.

Uhaku Regional Stage (upper Darriwilian) (Kiviõli ditch, Püssi locality, Lasnamägi locality, Uhaku valley, Osmussaar Island): limestones with layers of marly limestones and oil shale (kukersite).

Kukruse Regional Stage (lower Sandbian) (Kohtla quarry, Küttejõu quarry, Ubja quarry, Northern Kiviõli quarry, Vanaküla quarry, Oktoobri quarry, Kohtla-Järve locality, Tallinn (Punane Street), Kukruse quarry, Kohtla quarry, Lasnamägi locality, Ubja quarry, Alliku quarry, Harku quarry, Harku ditch): intercalation of limestone and oil shale (kukersite) layers of various thickness.

Haljala Regional Stage (Middle Sandbian) (Aluvere quarry, Jänese locality, Peetri locality, 


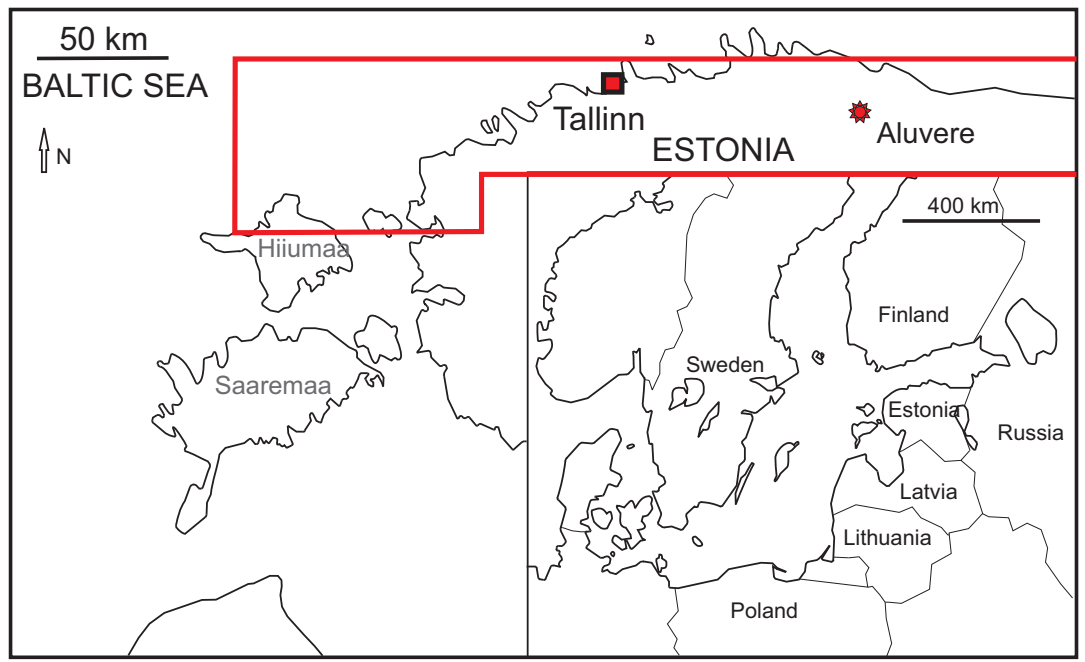

FIGURE 1. Location of northern Estonia. The area of Arachnostega gastrochaenae Bertling localities in the Ordovician of northern Estonia is marked with red.

Madise cliff, Pääsküla locality, Alliku quarry): marly limestones and marls.

Keila Regional Stage (upper Sandbian-lower Katian) (Keila quarry, Oandu locality, Aaspere ditch, Jälgimäe locality, Saue old quarry, Kasepere F-321 drill core): marly limestones and bioclastic limestones.

Vormsi Regional Stage (middle Katian) (Paope locality, Kõrgessaare outcrop, Saunja quarry): marly limestones with thin layers of marls.

Pirgu Regional Stage (upper Katian) (Paope locality, Hosholm locality): pure limestones with layers of marls.

All steinkerns in this study are limestone and were naturally weathered out of marly limestones. The pre-Katian specimens contain more clay and the Katian specimens are made of pure limestone. The bivalve specimens are steinkerns of complete shells. The empty tunnels were originally filled with calcite cement that was later dissolved due to weathering. The studied limestone steinkerns contain generally more clay in the Darriwilian and Sandbian and are more pure in the Katian. Studied steinkerns are similar in size and shape regardless of stratigraphic level. Sizes of studied molluscs were: gastropods $0,3-16 \mathrm{~cm}$, bivalves: $1-7 \mathrm{~cm}$, cephalopods: $2-60 \mathrm{~cm}$, hyolithids: $2-11 \mathrm{~cm}$. The host molluscs include: hyolithids (Dorsolinevitus, Crispatella, Hyolithes), bivalves (Ambonychia, Ahtioconcha, Aristerella, Cleionychia, Cypricardinia, Cyrtonota, Dystactella, Modiolopsis, Orthonota, Tancrediopsis, Veimarnella), gastropods (Brachytomaria, Bucanella, Bucania, Cataschisma, Cyclonema, Cymbularia, Deaechospira, Ecculio- mphalus, Eccyliopterus, Eotomaria, Fusispira, Holopea, Hormotoma, Kokenospira, Lesueurilla, Lophospira, Loxoplocus, Maclurites, Megalomphala, Pachystrophia, Pararaphistoma, Proturritella, Salpingostoma, Sinuites, Subulites, Straparollus, Temnodiscus, Trochonema, Worthenia) and cephalopods (discosorids, endocerids, lituitids, orthocerids, tarphycerids).

All specimens were cleaned with water and brushes. The best preserved were photographed with a Nikon D7000 digital camera. Only the maximal diameters of each selected Arachnostega trace were measured on the photos digitally provided with a scale bar. Abundance data from the regional Keila Regional Stage (latest Sandbian to earliest Katian) were not included in the analyses of Arachnostega abundance for global stages (i.e., Darriwilian, Sandbian, Katian). In order to check the statistical differences in Arachnostega infestation rates between different substrates and different ages, a non-parametric Mann-Whitney test was used (result is significant if $p<0.05$ ). All studied specimens are deposited at the Institute of Geology, Tallinn University of Technology (GIT) under collection numbers $251,337,334,362,399,404$, 694, 695, 696, and 697.

\section{RESULTS}

Arachnostega traces are common in the Middle and Upper Ordovician of Estonia, occurring in gastropods, bivalves, cephalopods and hyoliths. The Ordovician gastropods of northern Estonia contain Arachnostega traces from the Kunda Regional Stage (early Darriwilian) to the Pirgu 


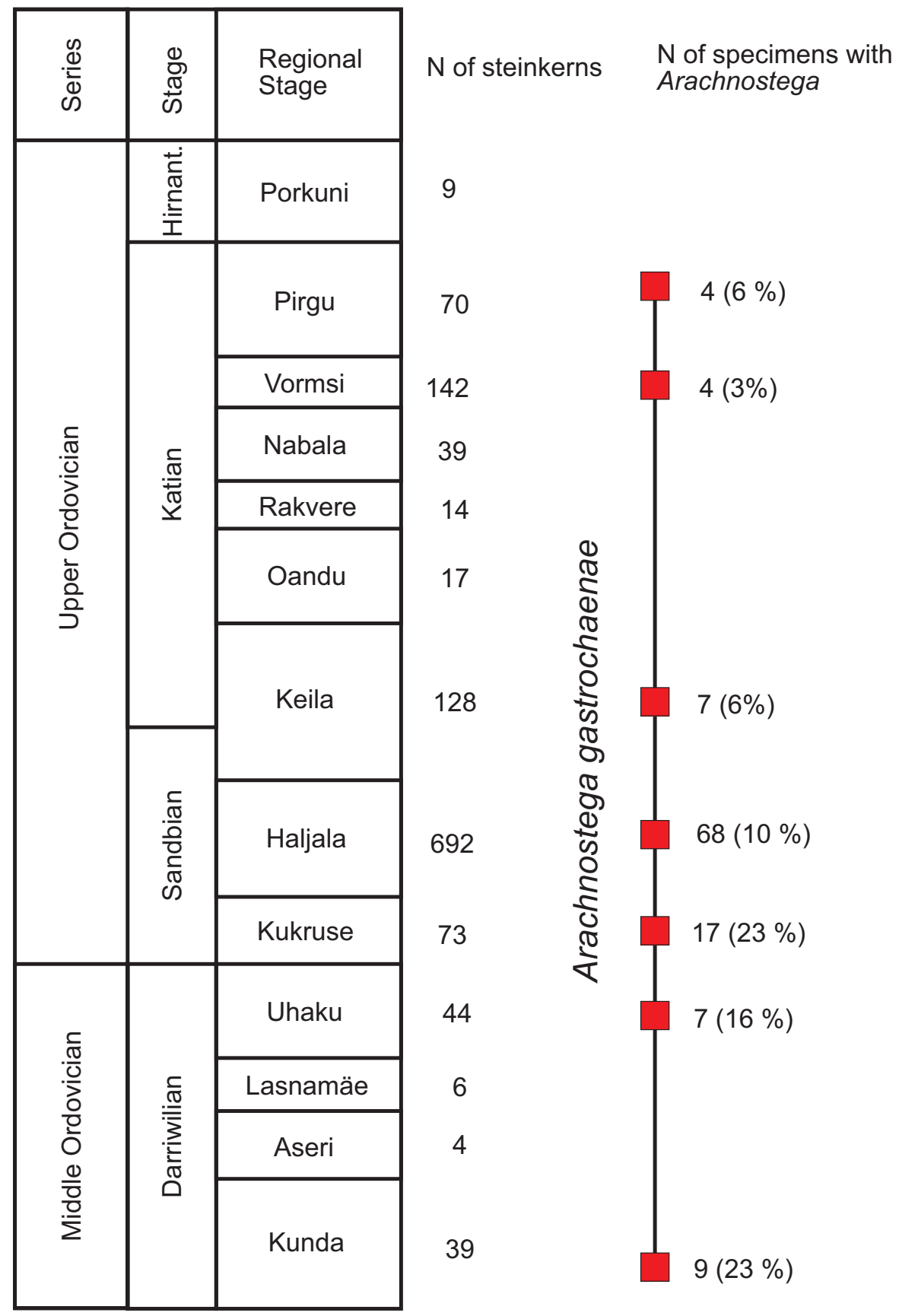

FIGURE 2. Stratigraphic distribution and abundance of Arachnostega gastrochaenae Bertling in the Ordovician gastropods of Estonia.

Regional Stage (latest Katian) (Figure 2). The percentages of gastropods with Arachnostega vary from 3\% in the Vormsi Regional Stage (late Katian) to $23 \%$ in the Kukruse Regional Stage (early Sandbian). Arachnostega does not show preference for specific areas of the substrate. No signs of re-burrowing were observed. Some burrows are filled with sediment or calcite cement; some are empty. Gastropods from several stages revealed no
Arachnostega traces (Figure 2). Arachnostega selectively burrowed certain sediment-filled shells. In the Aluvere Quarry (Sandbian), the highest abundance of Arachnostega is associated with bivalves $(26 \%)$ and the lowest with gastropods $(12 \%)$ (Table 1). A Mann-Whitney test found significant differences $(p<0.01)$ in Arachnostega abundance between bivalves and gastropods. Arachnostega was most abundant in the Darriwil- 
TABLE 1. Occurrence of Arachnostega in the Aluvere Quarry (Sandbian).

\begin{tabular}{|lcc|}
\hline \multicolumn{1}{|c}{ Taxa } & $\begin{array}{c}\text { Total number } \\
\text { of specimens }\end{array}$ & $\begin{array}{c}\text { Number of specimens with } \\
\text { Arachnostega }\end{array}$ \\
\hline Gastropoda & 506 & $60(12 \%)$ \\
Bivalvia & 106 & $28(26 \%)$ \\
Cephalopoda & 70 & $13(19 \%)$ \\
Hyolitha & 16 & $3(19 \%)$ \\
\hline
\end{tabular}

TABLE 2. Distribution of Arachnostega in gastropods from the Ordovician (global stages) of Estonia.

\begin{tabular}{|lcc|}
\hline \multicolumn{1}{|c}{ Stage } & Total gastropods & $\begin{array}{c}\text { Gastropods with } \\
\text { Arachnostega }\end{array}$ \\
\hline Katian & 282 & $8(3 \%)$ \\
Sandbian & 765 & $85(11 \%)$ \\
Darriwilian & 93 & $16(17 \%)$ \\
\hline
\end{tabular}

TABLE 3. Arachnostega diameter in gastropods in the Ordovician of Estonia.

\begin{tabular}{|lc|}
\hline \multicolumn{1}{|c|}{ Stage } & Arachnostega burrows diameter in gastropods \\
\hline Katian & $0.35-1.14 \mathrm{~mm}(\mathrm{~N}=7$, Mean $0.55, \mathrm{sd} 0.28)$ \\
Sandbian & $0.22-1.00 \mathrm{~mm}(\mathrm{~N}=37$, Mean $0.57, \mathrm{sd} 0.23)$ \\
Darriwilian & $0.24-1.37 \mathrm{~mm}(\mathrm{~N}=15$, Mean $0.76, \mathrm{sd} 0.34)$ \\
\hline
\end{tabular}

ian ( $17 \%$ of gastropods), slightly less abundant in the Sandbian (11\% of gastropods) and least abundant in the Katian (3\% of gastropods) (Table 2). A Mann-Whitney test found significant differences in Arachnostega abundance between the Sandbian and Katian $(p<0.01)$ and between the Darriwilian and Katian $(p<0.01)$. The diameter of Arachnostega tubes is relatively similar in all studied substrate shells in the Aluvere Quarry, though slightly larger in cephalopods (see description). The diameter of Arachnostega is similar throughout the Ordovician in northern Estonia (Table 3).

\section{DISCUSSION}

\section{Stratigraphic Distribution and Paleobiogeography}

Arachnostega traces are not known from the clastic sediments of the Lower Ordovician of Estonia. Arachnostega traces first appear in the Kunda Regional Stage (early Darriwilian) and are associated with the carbonate part of the Ordovician section (i.e., Middle and Upper Ordovician). In the Darriwilian, Arachnostega traces occur in the Kunda and Uhaku regional stages. The absence of Arachnostega in the Aseri and Lasnamägi regional stages could be explained by very small sample sizes. In the Sandbian, Arachnostega occurs both in the Kukruse and Haljala stages. The Arachnostega abundance in the Kukruse Regional Stage
(23\% of gastropods) is highest for the Ordovician of Estonia. However, in the following Keila Regional Stage (latest Sandbian to earliest Katian), Arachnostega abundance declines to $6 \%$ of gastropods. There is a gap in the Arachnostega distribution in the early Katian (Oandu to Nabala regional stages). This gap probably represents a very low abundance of Arachnostega rather than their real absence in the section because the sample sizes are not large enough. The lack of Arachnostega in the Hirnantian is most likely due to the very small sample size $(\mathrm{N}=9)$. The different average abundances of Arachnostega in the different stages may have some correlative value within the same paleoenvironment (Figure 2).

The most numerous records of Arachnostega in the Ordovician are from Gondwana and the Armorican Terrane Assemblage (Fatka et al., 2011). Slightly fewer records are from Kazakhstania and Baltica (Fatka et al., 2011). South American and African Gondwana and Armorican terrane assemblages were located in cold to temperate climatic zones during the Ordovician. It is possible that Arachnostega trace-makers preferred a cold climate, or the Arachnostega type of behavior was more successful in such climate regime. However, for steinkerns to be collectible they have to be separated from the matrix, and that requires particular rock types. Pure limestones and dolomites, for example, are unlikely to yield many free steinkerns, which biases the paleogeographic distribution away from certain regions, especially tropical settings far from a source of terrigenous sediment.

\section{Substrate Shell Selectivity}

Arachnostega is known from several types of invertebrate steinkerns, such as those of trilobites (Fatka et al., 2011), bivalves, cephalopods, gastropods and hyolithids. The burrows were originally filled with the sediment or calcite cement, and their fillings were often later dissolved during the weathering. There are several factors that can influence the Arachnostega abundance in particular skeleton, such as accessibility of shell cavity, sediment texture, available space in the shell for the Arachnostega network, nutrient content of the sediment and availability of shells in the Arachnostega biotope. The data from the Aluvere Quarry indicate that Arachnostega was substrate shell selective (Table 1). The trace-makers clearly preferred bivalves $(26 \%)$ over the gastropods $(12 \%)$. Both gastropods and bivalves were abundant in the Aluvere Quarry community. It is possible that the more spacious bivalve shells contained more food than 
gastropod shells, or that feeding on their less curved inner surfaces was easier than in gastropod shells. In this case, Arachnostega trace-makers may have been able to choose the shells they inhabited and exploited. In the case of closed bivalve shells, the more protected microenvironment may have been more conducive for burrowing. Another possible explanation is that generally infaunal bivalves may have possibly contained more food (the carcass), which was preserved more or less in situ. In contrast, gastropod shells were more commonly reworked and only rarely contained the carcass.

\section{Morphometric Variability}

Arachnostega has no obvious morphotypes associated with particular shell substrates. This indicates that substrates had no influence on the trace morphology. The morphology of Arachnostega traces shows no stratigraphic trends; both Darriwilian and Katian traces are similar. The same applies for the diameter of Arachnostega tubes that does not significantly change through the Ordovician (Table 3). However, the burrows with larger diameters tend to be slightly more common in the Darriwilian than in the Sandbian or Katian. Arachnostega traces in different substrates have relatively similar diameters, although traces in the cephalopods $(\mathrm{N}=9$, Mean $0.9 \mathrm{~mm}, \mathrm{sd}=0.36)$ tend to be larger than those in bivalves $(\mathrm{N}=11$, Mean 0.40 $\mathrm{mm}, \mathrm{sd}=0.12$ ). This may indicate that the generally larger cephalopod shells were preferred by larger Arachnostega trace-makers (i.e., larger animals). Some specimens (Figure 3.5) have primary tunnels that are wider than their branches. It is possible that the burrowing animal used the primary tunnels mostly for changing locations and created the branches for searching the food.

\section{Dynamics of Arachnostega Abundance in the Ordovician of Baltica}

Arachnostega abundance decreased significantly during the Ordovician in Baltica. It is not possible to determine whether this decrease involves the-trace makers themselves (a particular taxon or taxa) or if it reflects a change in the preferred behavior of the trace-maker(s).

Climatic change. The change of Arachnostega abundance in Baltica correlates well with the regional climatic change that took place as the paleocontinent moved from the temperate climate zone to the tropics during the Middle and early Late
Ordovician. This change may have played an important role in the decrease of Arachnostega abundance. The climatic change caused changes in the sedimentation environment such as faster sedimentation rates (based on thicker sections) and appearance of carbonate buildups and reefs (Nestor and Einasto, 1997). It is possible that Arachnostega may have preferred colder climates to tropical carbonate accumulation environments. The different and more abundant benthos in the tropics may have been among the direct causes behind the decrease of Arachnostega abundance. However, the possibility that the increased water temperature also affected Arachnostega cannot be ruled out.

GOBE. The change of Arachnostega abundance correlates well with the Great Ordovician Biodiversification Event (GOBE). Alternatively, or in addition to the regional climatic change, Arachnostega abundance may reflect the changes in marine communities that took place due to the GOBE, especially the appearance of new strategies of scavenging and predation. The GOBE may have affected Arachnostega via increased levels of bioturbation and possibly also the appearance of various new benthic predators. In modern marine environments, predation on rapidly reproducing invertebrates typically does not go so far as to wipe them out, but it may cause an adaptive change in behavior (Barnes and Hughes, 1999). If the decrease of Arachnostega abundance reflects the biotic changes caused by GOBE, it should be a global phenomenon and recognizable on other paleocontinents. Future studies should show whether the GOBE had an influence on the global abundance of Arachnostega in the Ordovician.

\section{CONCLUSIONS}

1. It is possible that Arachnostega trace-makers preferred a cold climate, or the Arachnostega type of behavior was more successful in such a climate regime.

2. The data from the Aluvere Quarry indicate that Arachnostega was substrate shell selective and clearly preferred bivalves $(26 \%)$ over the gastropods (12\%).

3. Arachnostega abundance decreased significantly during the Ordovician in Baltica possibly due to a climatic change from temperate to tropical. GOBE may have also influenced the abundance of Arachnostega. 

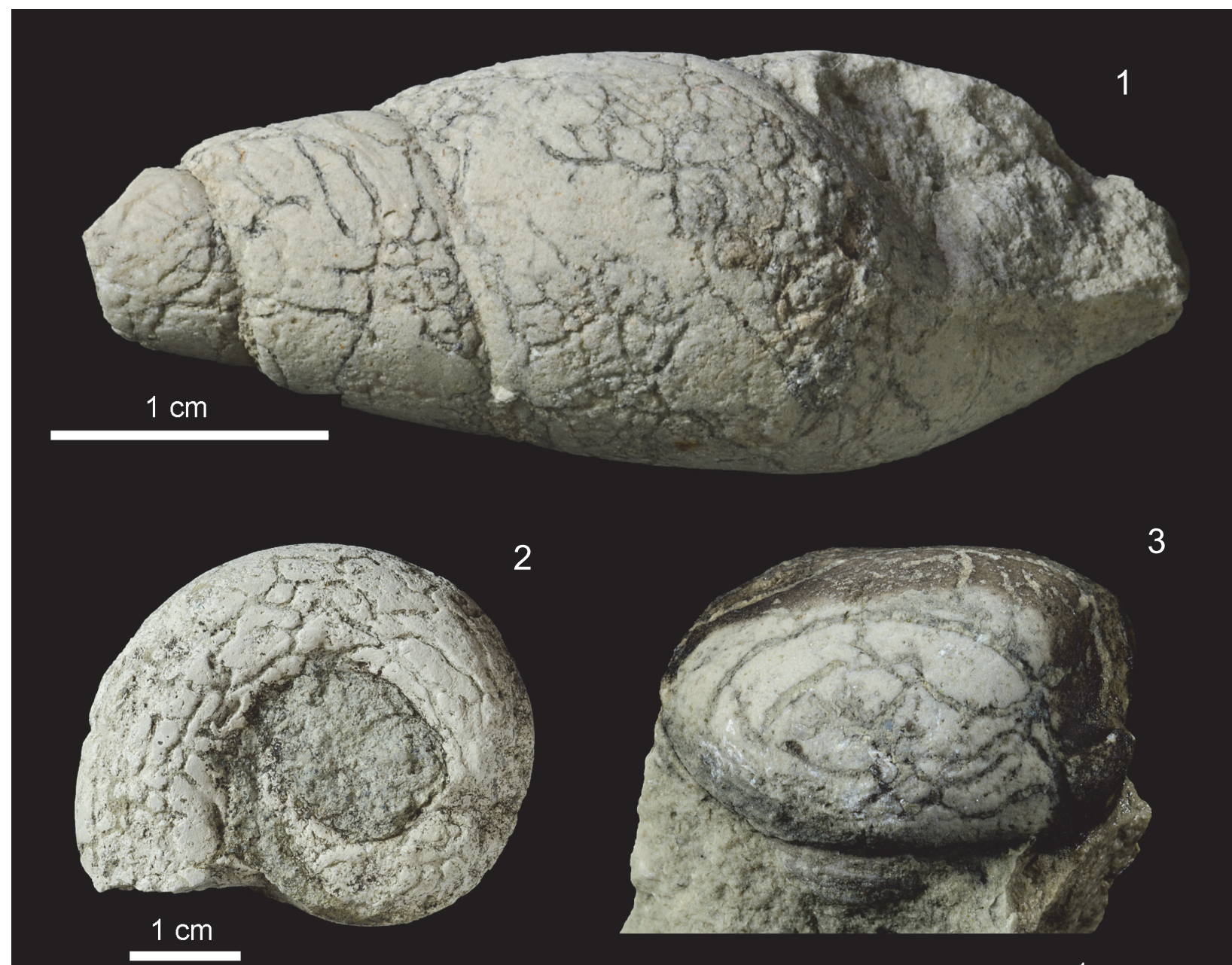

2


$1 \mathrm{~cm}$

FIGURE 3.1. Arachnostega gastrochaenae Bertling in a gastropod from Haljala Regional Stage (Sandbian), Aluvere Quarry, northern Estonia. GIT 399-948-1. 2. Arachnostega gastrochaenae Bertling in a gastropod from the Kunda Regional Stage (Darriwilian), Kunda Ojaküla, northern Estonia. GIT 404-355-1. 3. Arachnostega gastrochaenae Bertling in a bivalve from the Haljala Regional Stage (Sandbian), Aluvere Quarry, northern Estonia. GIT 399-1590-1. 4. Arachnostega gastrochaenae Bertling in a bivalve from the Haljala Regional Stage (Sandbian), Aluvere Quarry, northern Estonia. GIT 399-1601-1. 5. Arachnostega gastrochaenae Bertling in a cephalopod from the Uhaku Regional Stage (Darriwilian), Püssi, northern Estonia. GIT 695-12-1. 


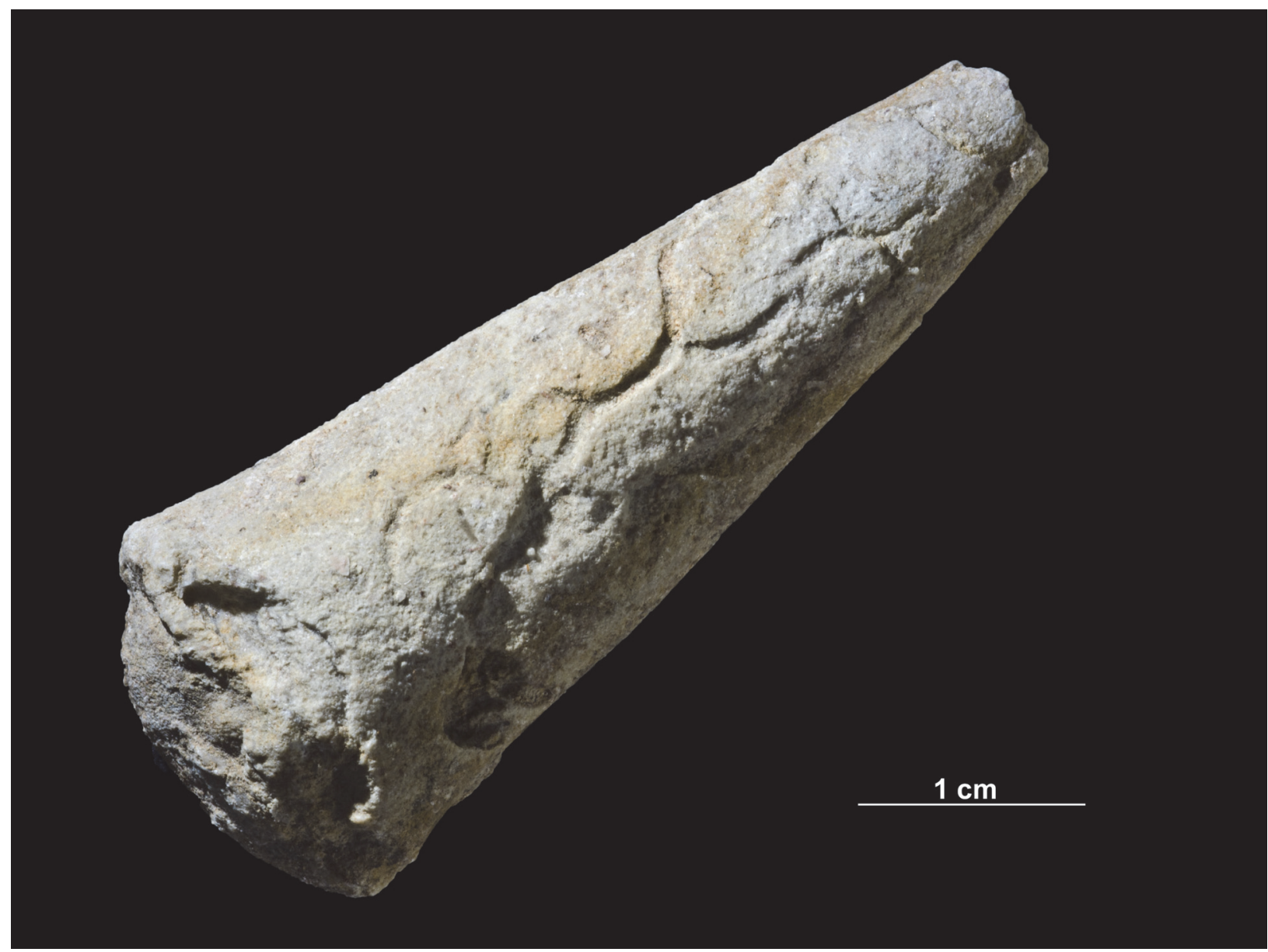

FIGURE 4. Arachnostega gastrochaenae Bertling in a hyolith from Kukruse Regional Stage (Sandbian), Harku, northern Estonia. GIT 696-15-1.

\section{SYSTEMATIC ICHNOLOGY}

Ichnogenus ARACHNOSTEGA Bertling, 1992

Type ichnospecies. Arachnostega gastrochaenae Bertling, 1992.

\section{Arachnostega gastrochaenae Bertling, 1992 Figures 3-4}

2002. Arachnostega gastrochaenae Bertling; Aceñolaza and Aceñolaza, p. 182, fig. 6D.

2011 Arachnostega gastrochaenae Bertling; Fatka et al., p. 372-375, text-figs. 4, 5 .

2013 Arachnostega gastrochaenae Bertling; Aceñolaza et al., p. 315-322. (see for synonymy).

Description. Straight, curved or angular tunnels that form burrows or burrow systems on the surface or at partial contact with the surface of steinkerns of skeletal fossils (bivalves, gastropods, cephalopods, hyolithids). Most common simple forms are usually branching at an angle of $45-90^{\circ}$, but the branching patterns are variable. Less common are burrow systems that form irregular, polygonal meshes. The tunnels have rounded cross-sections. The diameters of burrows in each system vary on molds depending on how they are exposed on the steinkern. The largest systems can occupy the whole interior of the substrate shell. Arachnostega traces can occur in gastropods throughout their shell interiors.

Dimensions (mm). Tunnel diameter in bivalves: $0.22-0.59(\mathrm{~N}=11$, Mean 0.40, $\mathrm{sd}=0.12)$, diameter in gastropods: $0.22-1.20 \quad(\mathrm{~N}=37$, Mean 0.57 , $\mathrm{sd}=0.23$ ), diameter in cephalopods: 0.43-1.36 $(\mathrm{N}=9$, Mean 0.9, $\mathrm{sd}=0.36)$

\section{ACKNOWLEDGEMENTS}

We thank two anonymous reviewers for suggesting improvements to our submitted manuscript. O.V. is indebted to a Sepkoski Grant (Paleontological Society), the Palaeontological Association Research Grant program, Estonian 
Science Foundation grant ETF9064 and Estonian Research Council grant IUT20-34 for financial support. M.W. thanks the Faculty Development Fund at The College of Wooster. This paper is a contribution to IGCP 591 "The Early to Middle Paleozoic Revolution."

\section{REFERENCES}

Aceñolaza, G. and Aceñolaza, F.G. 2002. Ordovician trace fossils of Argentina. In aspects of the Ordovician System in Argentina. In Aceñolaza, F.G. (ed.), INSUGEO, Serie Correlación Geológica, 16:177194.

Aceñolaza, G., Gutiérrez-Marco, J.C., and Peralta, S. 2013. Arachnostega gastrochaenae Bertling (traza fósil) en las secuencias volcaniclásticas de la Formación Suri, Sistema de Famatina, Argentina. Ameghiniana, 40:315-322.

Barnes, R.S.K. and Hughes, R.N. 1999. An Introduction to Marine Ecology, 3rd Edition. Wiley-Blackwell.

Bertling, M. 1992. Arachnostega n. ichnog. - burrowing traces in internal moulds of boring bivalves (late Jurassic, Northern Germany). Paläontologische Zeitschrift, 66:177-185.

Cocks, L.R.M. and Torsvik, T.H. 2005. Baltica from the late Precambrian to mid-Palaeozoic times: the gain and loss of a terranes identity. Earth-Science Reviews, 72:39-66.
Fatka, O., Mikuláš, R., Szabad, M., Micka, V., and Valent, M. 2011. Arachnostega Bertling, 1992 in the Drumian (Cambrian) sediments of the Teplá-Barrandian region (Czech Republic). Acta Geologica Polonica, 61:367-381.

Fatka, O. and Kozák, V. 2014. A new type of entombment of Peronopsis (Agnostida) in a hyolithid conch. Carnets de Géologie, 14:191-198.

Gil Cid, M.D. and Lebrón Moreno, J.A. 2010. Taphonomy of trilobites and associated invertebrates from SW Spain and NW Portugal. Neues Jahrbuch für Geologie und Paläontologie, Abhandlungen 257:169-179.

Mikuláš, R. and Dronov, A.V. 2005. Trace Fossils, p. 3338. In Dronov, A.V., Tolmacheva, T., Rayevskaya, E., and Nestell, M. (eds.), Cambrian and Ordovician of St Petersburg Region. St Petersburg State University and A.P. Karpinsky All-Russian Research Geological Institute, St. Petersburg.

Mõtus, M.A. and Hints, O. 2007. Excursion Guidebook. In 10th International Symposium on Fossil Cnidaria and Porifera. Excursion B2: Lower Paleozoic geology and corals of Estonia. August 18-22, 2007. Institute of Geology at Tallinn University of Technology, Tallinn.

Nestor, H. and Einasto, R.1997. Ordovician and Silurian carbonate sedimentation basin, p. 192-204. In Raukas, A. and Teedumäe, A. (eds.), Geology and Mineral Resources of Estonia. Estonian Academy Publishers, Tallinn.

Torsvik, T.H., Smethurst, M.A., van der Voo, R., Trench, A., Abrahamsen, N., and Halvorsen, E.1992. Baltica. A synopsis of Vendian-Permian palaeomagnetic data and their palaeotectonic implications. Earth Science Reviews, 33:133-152. 